The Digital Object Identifier - DOI: 10.37952/ROI-jbc-01/19-57-1-72

Submitted on January 19, 2019.

\title{
Features of the chemical composition of crayfish
}

\author{
(C) Marina L. Kalayda, ${ }^{*+}$ Madina F. Khamitova, and Ilia A. Bogatyrev \\ Department of "Water Bioresources and Aquaculture." Kazan State Power Engineering University. \\ Krasnoselskaya St., 51. Kazan, 420066. Tatarstan. Russia. \\ Phone: +7 (843) 519-43-53. E-mail: kalayda@mi.ru
}

$\overline{\text { *Supervising author; }{ }^{+} \text {Corresponding author }}$

\begin{abstract}
The cultivation of crayfish in the structure of aquaculture in the Middle Volga region can be an important component. Currently, natural crayfish populations in the Republic of Tatarstan include 2 species narrow-toed crayfish (Pontastacus leptodactylus Esch.) and wide-toed crayfish (A. astacus L.). The development of aquabiological technologies allows the use of natural crayfish populations for the tasks of creating industrial breeding farms.

In connection with the global trend of the growing popularity of crayfish in food use, the importance of research on the chemical composition of crayfish as objects of consumption grows.

The chemical analysis of narrow-fingered crayfish revealed 13 elements, of which calcium is found in maximum amount in the dry residue. The calcium content in the narrow crayfish was $154.057 \mathrm{~g} / \mathrm{kg}$ dry weight (fig. 1), the chitinous shell of crayfish contains relatively more calcium - up to $376.282 \mathrm{~g} / \mathrm{kg}$ of dry weight.

The following sequences of the content of chemical elements in crayfish from the Kuibyshev reservoir are noted:

$>$ in the muscle tissue of edible parts $\mathrm{Ca}>\mathrm{K}>\mathrm{S}>\mathrm{P}>\mathrm{Cu}>\mathrm{Fe}>\mathrm{Zn}>\mathrm{Mn} \sim \mathrm{Br}>\mathrm{Sr}$;

$>$ in the shell $\mathrm{Ca}>\mathrm{Si}>\mathrm{P}>\mathrm{S}>\mathrm{K}>\mathrm{Sr}>\mathrm{Ti}>\mathrm{Fe}>\mathrm{Mn}>\mathrm{Cu}>\mathrm{Br}>\mathrm{Zn}>\mathrm{As}$.

In crayfish from the Kuibyshev reservoir we studied, the raw muscle mass of the edible parts of the crayfish contained $88.80 \%$ of water, $10.28 \%$ of organic substances and $0.92 \%$ of mineral substances, and in the chitin-containing raw shells of crayfish, respectively, contained $59.2 \%$ of water, $36.42 \%$ organic matter and $4.38 \%$ mineral matter.

The particular interest is the study of crayfish shells, since they consist mainly of chitin. It is a bearing polysaccharide for invertebrate, reaching $85 \%$ of the weight of the integuments. In the cuticle of arthropods, chitin forms composite complexes with proteins, pigments, calcium salts. In the composition of the shells of crayfish, $376282 \mathrm{mg} / \mathrm{kg}$ dry mass of calcium is noted. In smaller quantities phosphorus, potassium, iron and zinc are noted. Titanium was found in crayfish shells in the amount of $1845 \mathrm{mg} / \mathrm{kg}$ dry weight and was not found in their muscle tissue and other aquatic organisms in the region.

In the studied crayfish, the content of heavy metals in the wet mass was: $\mathrm{Zn}-0.42 \mathrm{mg} / \mathrm{kg}$; $\mathrm{Cu} 6.5$ $\mathrm{mg} / \mathrm{kg} ; \mathrm{Fe}-1.39 \mathrm{mg} / \mathrm{kg} ; \mathrm{Sr}-0.23 \mathrm{mg} / \mathrm{kg}$. Residual amounts of zinc and copper in the muscular tissue of the edible parts of crayfish of the Kuibyshev reservoir are within the normal range.

The content of hazardous elements (lead, arsenic, cadmium and mercury) in the crayfish from the Kuibyshev reservoir is within the sanitary and epidemiological norms, and in the Volga delta crayfish the lead content is exceeded.
\end{abstract}

\section{References}

[1] A.C. Alexandrov, I.N. Zadoyenko, N.Z. Stroganova. State of stocks, problems of protection and reproduction of crayfish in the waters of Russia. Problems of protection, rational use and reproduction of crayfish. Moscow: Medinor. 1997. P.6-14. (russian)

[2] S.Y. Brodsky. Astacidae of the Kiliya Danube Delta Reservoirs and Some Considerations on the origin of the Crayfish in the North-Western Black Sea Coast / Limnological studies of the Danube. Kiev: Naukova Dumka. 1969. P.308-315.

[3] G.H. Ilyasov, E.I. Melyakin. Features of the micronutrient composition of the organism of crayfish (Astacus fluviatilis). ASTU Herald. Ser. Fish industry. 2011. No.1. P.87-89. (russian)

[4] Crayfish catching and breeding on the waters of the European part of Russia (Handbook). Saint Petersburg. 2006. 207p. (russian)

[5] V.B. Ilyin. Elemental chemical composition of plants. Novosibirsk: The science. 1985. 129p. (russian)

[6] S.A. Zernov. General hydrobiology. Moscow.-Leningrad: State pub. h. of biol. and med. literature. 1934. 503p. (russian) 
[7] M.L. Kalayda, and M.F. Khamitova. Plumatella fungosa (bryozoa) in the composition of hydrobiocenosis of mobile bioplato as an accumulator of contaminants. Butlerov Communications. 2014. Vol.37. No.2. P.127-130. ROI: jbc-02/14-37-2-127

[8] M.D. Mukatov, N.A. Kirichko, E.N. Romanenkova. Qualitative characteristics of chitin and chitosan obtained from shell-containing wastes of crayfish. MSTU Herald. 2015. Vol.18. No.4. P.641-646. (russian)

[9] Biological encyclopedic dictionary. Ch. ed. M.S. Gilyarov; Ed. Board. A.A. Bayev, G.G. Winberg and others. 2nd ed. Corr. Moscow: Scientific pub. house: «Great Russian Encyclopedia». 1989. 864p. (russian)

[10] R.A.A. Muzzarelli, C. Jeuniaux, G.W. Gooday. Chitin in nature and technology. Plenum Press, New York. 1986. 420p.

[11] K.D. Zhogolev, V.U. Nikitin, V.N. Tzigan, V.N. Yegorov. Chitosan in medicine and nutrition. Series: Medicine of the XXI century. St.Petersburg. 2000. 24p. (russian)

[12] O.Y. Mezenova, L.S. Baydalinova. Technology of food products of complex composition based on biological objects of aquatic fisheries: Study guide. Kaliningrad: FGOU VPO "KSTU". 2007. 108p. (russian)

[13] M.L. Kalaida, L.F. Uryadova, and A.R. Ashadulliva. Results of the study of aquatic organisms for heavy metal content in the conditions of varying degrees of anthropogenic stress. Butlerov Communications. 2010. Vol.22. No.12. P.61-66. ROI: jbc-02/10-22-12-61

[14] M.L. Kalayda, and M.F. Khamitova. Dreissena polymorpha pall. (mollusca) as a part of mobile bioplato hydrobicenosis as batteries of contaminats. Butlerov Communications. 2014. Vol.37. No.2. P.122-126. ROI: jbc-02/14-37-2-122

[15] T.D. Malyzheva. Zinc metabolism in carp under various environmental conditions: Dis... cand. of biol. science. Kiev. 1982. 24p.

[16] Guidelines for cleaning with artificial sorbents raw fish, contaminated with heavy metals. St. Petersburg: Publishing house GosNIORH. 1997. 26p. (russian)

[17] Raw materials and food products. Sample preparation. Mineralization for the determination of toxic elements: GOST 26929 - 94. App. 21.02.95. Moscow. 1994. 12p. (russian) 